UDC 629.735.02: 629.735.015.3 (045)

\author{
${ }^{1}$ N. F. Tupitsin, \\ ${ }^{2}$ A. S. Yurchenko, \\ ${ }^{3}$ I. C. Stepanenko
}

\title{
ONE METHOD TO DROP THE AVIATION OUTBOARD BLOCK WITH VARIABLE GEOMETRY
}

${ }^{1,2}$ Aviation Computer-Integrated Complexes Department, National Aviation University, Kyiv, Ukraine
E-mails: ${ }^{1}$ nift@mail.ru, ${ }^{2}$ ayurchenko@yahoo.com, ${ }^{3}$ STEPANENKO.iLay@gmail.com

Abstract - One method to drop the aviation outboard block with variable geometry is proposed. For grounding of this method the calculation and exploration of aerodynamic characteristics of the outboard block, which consists of the outward cylindrical body and inside a sharp body of rotation with a tail plumage, is performed. Estimation of the implementation possibility of a method to drop such block is carried out also.

Index Terms - Aviation outboard block; moving part of a block; aerodynamic characteristics.

\section{INTRODUCTION}

At application some types of aviation outboard blocks during the flight it's necessary to provide for their forced separation from the aircraft [1] - [3]. The most common methods of the aviation outboard block (AOB) separation from aircraft: shooting with the help of pyrocartridge or separation through the use of the pusher, which is located on aircraft [1], [2].

It is obvious that the discharge of AOB only with a help of weight force admissible in case of the aerodynamic forces, which are acting on the AOB considerably less than a value of weight. Otherwise, it's necessary to apply, for example, methods as described below.

In this article the ground of method for the AOB dropping is offered due to aerodynamic forces operating the aviation outboard block with changeable geometry.

Clearly that on the stage of planning of such aviation outboard block with changeable geometry the preliminary analysis of their aerodynamic and dynamic characteristics is needed. Such analysis will allow reasonably to choose needed mass-overall parameters of block construction and conditions of their safe application.

\section{PROBlem STATEMENT}

It is necessary to conduct a calculation and analysis of the basic aerodynamic characteristics of the AOB, made from a cylindrical outward body 1 and (central) inside being a sharp body of rotation with a tail plumage 2. Schematically the block is shown in the Fig. 1, thus movable part of the block is connected with the immobile flexible cowling 3, eliminating the transmission of the aerodynamic loading from one part to other and flowing of a stream in the inside of the block. The AOB is hanged to an aircraft with a help of castles mount 4 .
The task is to calculate and explore of aerodynamic characteristics of the AOB without a displacement of the moving part of a block (MPB) and with a displacement of the MPB. It also follows to estimate values of forces and moments, which is acting on the configuration of the AOB with displacement of the MPB.

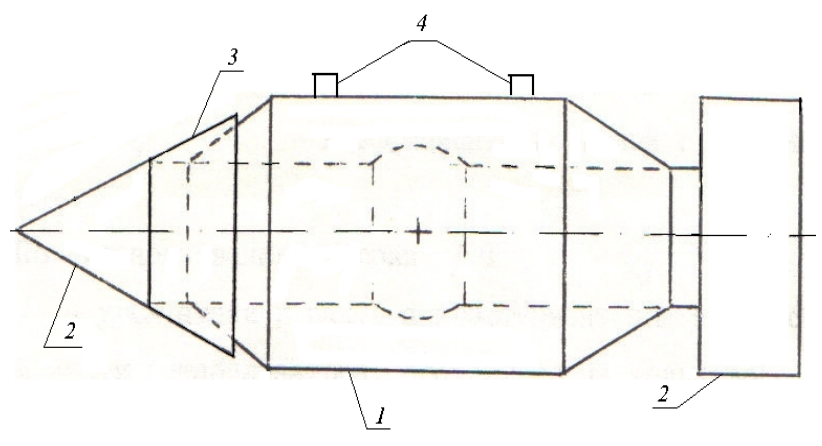

Fig. 1. The form of aviation outboard block

\section{THE TASK SOLUTION}

In our case, the use of the known methods of calculation of aerodynamic characteristics [4], [5] for the isolated movable part can give incorrect results in connection with absence of flowing around of its central component of a body.

At calculation of aerodynamic characteristics, we will consider movable part of a block, as a combination of head part and tail unit [4].

Thus, coefficient of lift force

$$
C_{y}^{m p}=C_{y}^{h}+C_{y}^{s t},
$$

where $C_{y}^{h}, C_{y}^{s t}$ are coefficients of lift force for a head part and tail unit.

According to the linearized theory [4]:

$$
C_{y}^{h}=2 \alpha
$$


where $\alpha$ is the an angle of attack in rad., and coefficient of lift force for tail unit (stabilizer, consisting of angular wing and rectangular wings, connecting it with a body)

$$
C_{y}^{s t}=\frac{4.8 \alpha\left(1+\frac{d}{D}\right)\left(1-\frac{d^{2}}{D^{2}}\right)\left[1+1.5\left(1-\frac{d}{D}\right)\right]}{1+0.8 \frac{d}{D}\left(1+\frac{d}{D}\right)\left[1+1.5\left(1-\frac{d}{D}\right)\right]},
$$

where $D, d$ are diameters of stabilizer and body.

Coefficient of pitch moment of the MPB

$$
m_{z}^{m p}=\left(C_{y}^{m p} x_{T}-m_{z}^{1 m p}\right) / l^{m p},
$$

where $x_{T}$ is the coordinate of body center mass, measured from the toe of MPB; $m_{z}^{1 m p}$ is a coefficient of pitch moment with respect to the toe of MPB.

The coefficient of pitch moment

$$
m_{z}^{1 m p}=3 \alpha x_{p}^{h}+C_{y}^{s t} x_{p}^{s t}
$$

where $x_{p}^{h}=2(1.05-1.1) l^{h} / 3$ is the coordinate of pressure center of (p.c.) MPB; $x_{p}^{s t}$ is the coordinate of pressure center of the tail unit.

Dependence of the lift force coefficient from the angle of attack is shown in a Fig. 2 (continuous line), and the experimentally-received points are symbols "+" there.

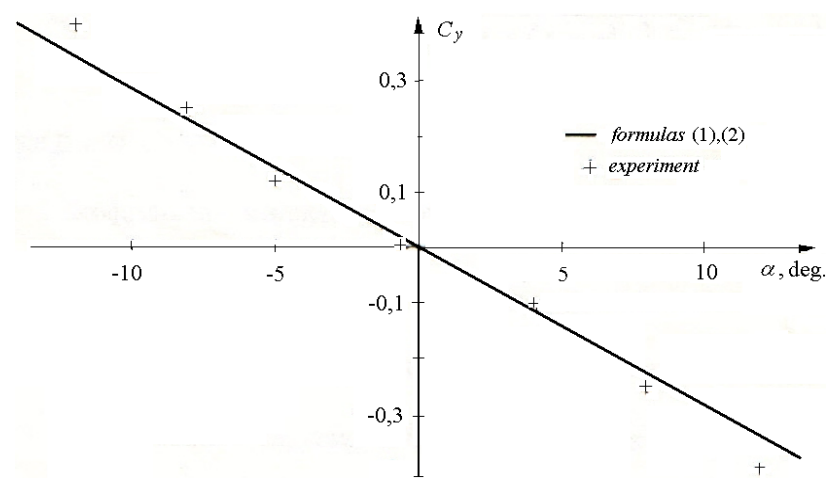

Fig. 2. Dependence of the coefficient $C_{y}$ from the angle $\alpha$

Dependence of the pitch moment coefficient of the MPB from an angle of attack is shown in Fig. 3 (continuous line), and the experimentally-received points are symbols "+" there.

Comparison of the calculated dependencies of coefficients $C_{y}^{s t}$ and $m_{z}^{m p}$ from angle $\alpha$, calculated according to the equations (1) - (4) and the experimental data shows the satisfactory accuracy of the calculation results.
Experimental data for subsonic airflow, namely at Mach number $M \leq 0.8$, are given. In this case, flow without separation around the tail moving part of a block is achieved by the smooth transition from the nose part to the outer cylinder and to the rear.

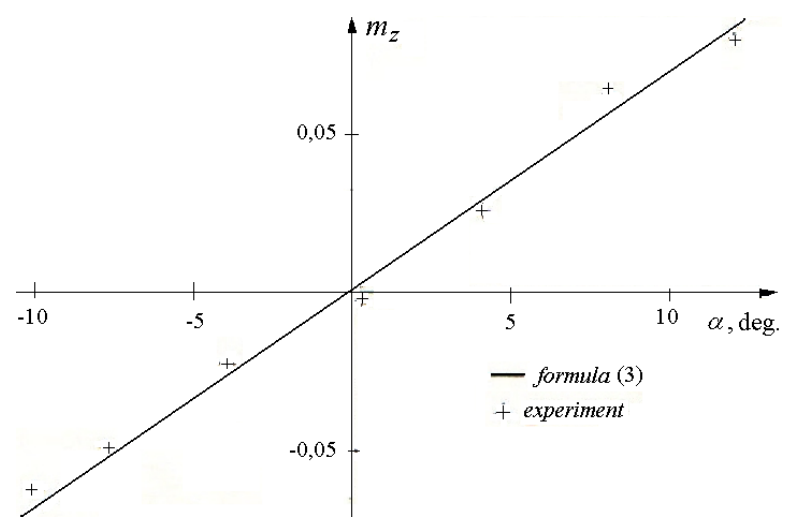

Fig. 3. Dependence of the coefficient $m_{z}$ of the MPB from an angle $\alpha$

In calculating the aerodynamic characteristics of the whole outboard block, the coefficient of lift force represented in the form

$$
C_{y}=C_{y}^{s t}+C_{y}^{c},
$$

where $C_{y}^{c}$ is a coefficient of lift force for cylindrical housing, and coefficient pitching moment

$$
m_{z}=\frac{m_{z}^{m p}+C_{y}\left(x_{T}-x_{p}^{c}\right)}{l^{c}}
$$

here $l^{c}$ is a coordinate of the center of pressure for cylindrical housing.

The drag of outboard block defined as sum of its resistance $\left(C_{x 0}\right)$ at an angle of attack $\alpha=0$ and inductive $\left(C_{x i}\right)$ resistance [4] :

$$
C_{x}=C_{x 0}+C_{x i} .
$$

The value $C_{x 0}$ equal to the sum of the profile $\left(C_{x p r}\right)$ and stern $\left(C_{x s t}\right)$ resistances and also base drag $\left(C_{x b d}\right)$ :

$$
C_{x 0}=C_{x p r}+C_{x s t}+C_{x b d} .
$$

The method of calculating the value $C_{x s t}$ is set out in the work [5]. Coefficient of profile resistance

$$
C_{x p r}=C_{x c}+C_{x f r},
$$

where $C_{x c}$ is a coefficient of cone resistance; $C_{x f r}$ is a coefficient of resistance of friction of the lateral block's surface, referred to the area of mid-section: 


$$
C_{x f r}=C_{f l} \frac{S_{l}}{S_{\text {mid }}}
$$

where $C_{f l}=0.427 /\left[(\lg \operatorname{Re}-0.407)^{2.46}\right] ; \quad \operatorname{Re}$ is the Reynolds number, $\operatorname{Re}=\frac{V_{\infty} l^{c}}{v_{\infty}} ; v_{\infty}$ is the dynamic coefficient of viscosity [5]; $V_{\infty}$ is the speed of incident flow.

Coefficient of base drag at subsonic speeds is defined as

$$
C_{x b d}=\frac{0.029}{\sqrt{C_{x f r}}}\left(\frac{d_{b o t}}{d_{c}}\right)^{3},
$$

where $d_{b o t}$ is the diameter of the block in finite part; $d_{c}$ is the cylinder diameter.

The coefficient of inductive resistance

$$
C_{x i}=C_{y}^{\alpha} \alpha+C_{x i n l},
$$

where $C_{x i n l}=-\xi \alpha^{2}$ is the coefficient of suction force; $\xi$ is the coefficient which depends on the shape of the nose part, particularly for the conical nose there is empirical dependence shown as:

$$
\xi=0.08\left(1+2 / \lambda_{s p} \sqrt{1-\mathrm{M}^{2}}\right),
$$

where $\lambda_{s p}$ is the aspect ratio of spout.

As it follows from analysis of expressions (5) (7), at turning MPB through an angle $\alpha$ relatively to the external cylindrical body (Fig. 4), its aerodynamic characteristics can be calculated separately.

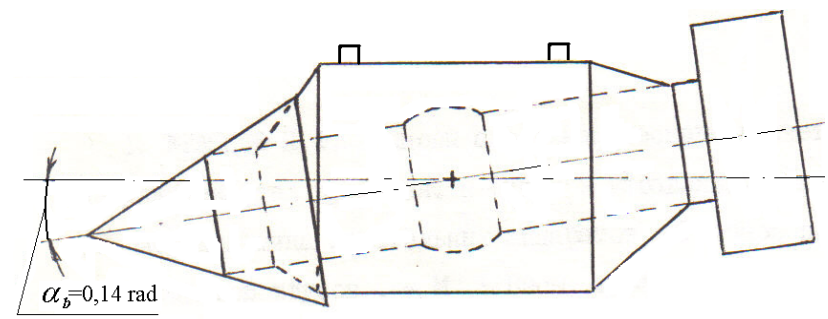

Fig. 4. The form of aviation outboard block with shifting of the MPB on an angle $\alpha_{b}$

Dependencies of aerodynamic forces coefficients $C_{y}, C_{x}$ and of aerodynamic moment coefficient $m_{z}$ of outboard block from angle of attack $\alpha_{b}$ without displacement MPB and with a fixed displacement MPB relatively to axis of external body on $0.14 \mathrm{rad}$. (8 deg) are shown in Fig. 5. As can be seen of the obtained dependencies minimum of coefficients of lift force and drag forces unit with displacement MPB reaches approximately at $\alpha_{b}=0.14 \mathrm{rad}$, and coefficient of block's pitching moment $m_{z}>0$ at $0<\alpha_{b}<0.21 \mathrm{rad}$ and $m_{z}<0$ at $\alpha_{b}>0.21 \mathrm{rad}$ in considered range of angles $\alpha_{b}$.

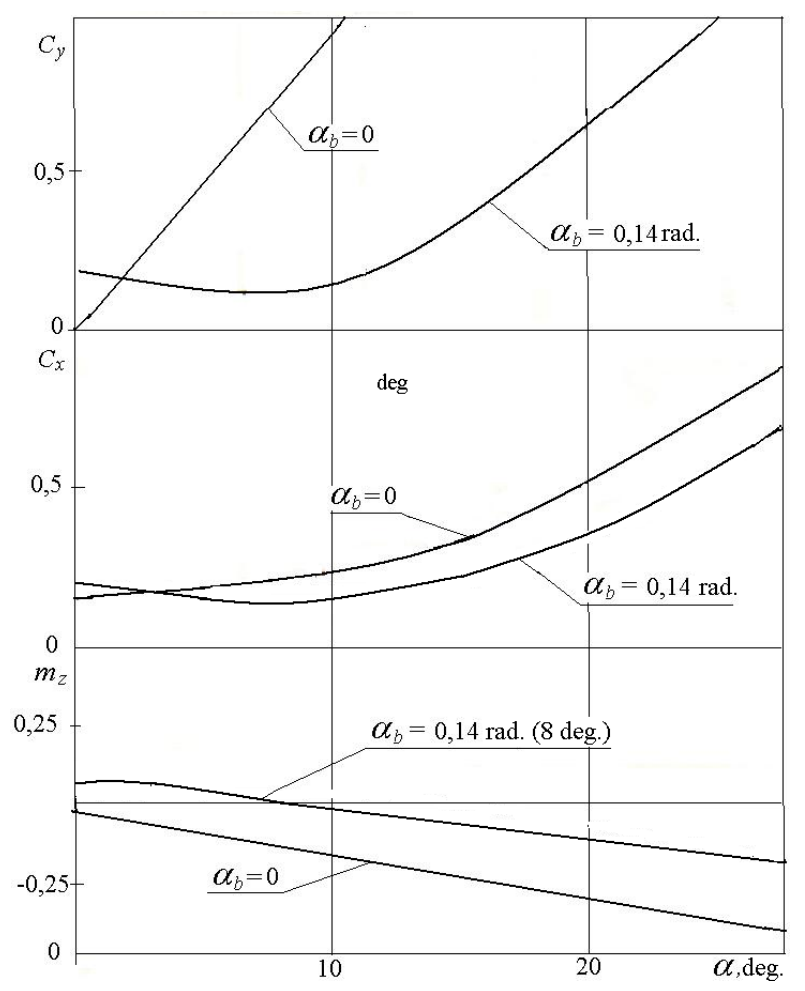

Fig. 5. Dependencies of aerodynamic coefficients $C_{y}, C_{x}$ and $m_{z}$ of the AOB from an angle $\alpha_{b}$

\section{THE IMPLEMENTATION POSSIBILITY OF THE PROPOSED METHOD}

For implementation possibility of the proposed method, we shall calculate the lift and drag forces and then compare these values with the AOB weight. Besides, we'll estimate a dynamic of the AOB rotary motion after its separation from the aircraft.

The system of differential equations, which describes the movement of $\mathrm{AOB}$ in a vertical plane after its dropping from the aircraft, has the form [3]:

$$
\left\{\begin{array}{l}
m \dot{V}=-X-Q \sin \theta ; \\
m V \dot{\theta}=Y-Q \cos \theta ; \\
\dot{\vartheta}=\omega_{z} ; \\
J_{z} \dot{\omega}_{z}=M_{z},
\end{array}\right.
$$


where $m, Q, J_{z}$ is the mass, weight and an inertia moment of AOB; $X, Y, M_{z}$ is the drag, lift forces and pitch moment of the AOB; $\theta$ is the angle of velocity vector inclination to the horizon plane.

It is necessary to find a solution of (8) for the specified initial conditions.

We find an approximate solution of (8) under the following assumptions:

- the speed of the AOB is not greatly reduced in the considered interval $\left[t_{1}, t_{2}\right]$, i.e. can accept $V_{\infty}=V \approx$ const;

- coefficients of the pitch moment and lift force can write in the form: $m_{z}=m_{z}^{\alpha} \alpha+m_{z}^{\omega_{z}} \omega_{z} ; c_{y}=c_{y}^{\alpha} \alpha$.

At these assumptions (8) takes the form:

$$
\left\{\begin{array}{l}
\dot{\theta}=A_{1}(\vartheta-\theta)-A_{2} \\
\dot{\vartheta}=\omega_{z} \\
\dot{\omega}_{z}=A(\vartheta-\theta)+A_{3} \omega_{z}
\end{array}\right.
$$

where $A=\frac{m_{z}^{\alpha} \rho V^{2} s l}{2 I_{z}} ; \quad A_{1}=\frac{C_{y}^{a} \rho V s}{2 m} ; \quad A_{2}=\frac{g}{V} \cos \theta ;$ $A_{3}=\frac{m_{z}^{\omega_{z}} \rho V^{2} s l}{2 I_{z}} ; \vartheta-\theta=\alpha$.

After the decomposition of the function $\cos \theta$ at Taylor series and discarding the second-order terms the coefficient $A_{2}=\frac{g}{V}$. At aircraft velocity $V \geq$ $\geq 200 \mathrm{~m} / \mathrm{s}$, the value $V$ is not greater 0,05 and the summand $A_{2}$ we can neglect. Since a value $c_{y}^{\alpha} \approx 0$ in the angle range $0 \leq \alpha \leq 15 \mathrm{deg}$, according to Fig. 5 , then $\dot{\theta} \simeq 0$ and at $\theta(0)=0$ a value $\vartheta=\alpha$. In this case from (9), we have differential equation second order

$$
\ddot{\alpha}-A_{3} \dot{\alpha}-A \alpha=0 .
$$

This is an equation of free oscillations. Assume that the aircraft with AOB has next flight parameters: the height $H=100 \mathrm{~m}$; the velocity $200 \mathrm{~m} / \mathrm{s}$. Assume also that the AOB has next parameters: mass $m=165 \mathrm{~kg}$; an inertia moment $I_{z}=55 \mathrm{~kg} \cdot \mathrm{m}^{2}$; coefficient $m_{z}^{\omega_{z}}=-0.021 ; l=2 m ; s=0.52 m^{2}$. So, the value $A_{3}=-9.729 \mathrm{~s}^{-1}$ and the value $A$ changes approximately from $157.513 s^{-2}$ to $-157.513 s^{-2}$ at changing of the AOB angle $\alpha$ from 0 to $30 \mathrm{deg}\left(-0.34 \leq m_{z}^{\alpha}\right.$ $\leq 0.34$ ). Numerical calculations (10) in Matlab 7.8.0 for different initial data of the AOB dropping prove a stable trajectory of its motion after separation from the aircraft (Fig. 6). The time of passing of the static instability plot depends on initial data and changes from $0.15 s$ (Fig. 6c) to $0.6 s$ (Fig. 6a).

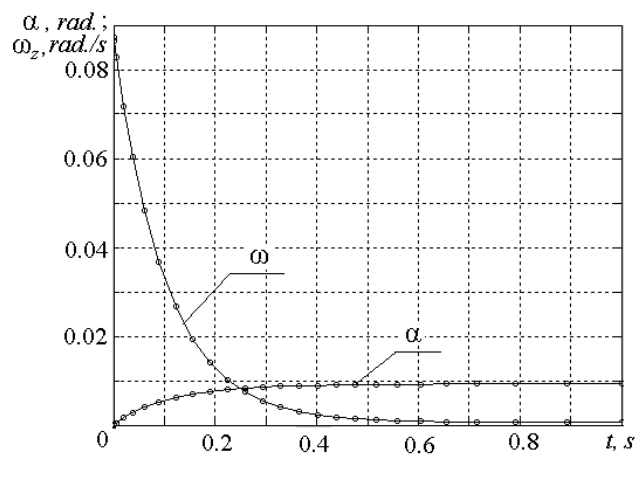

a
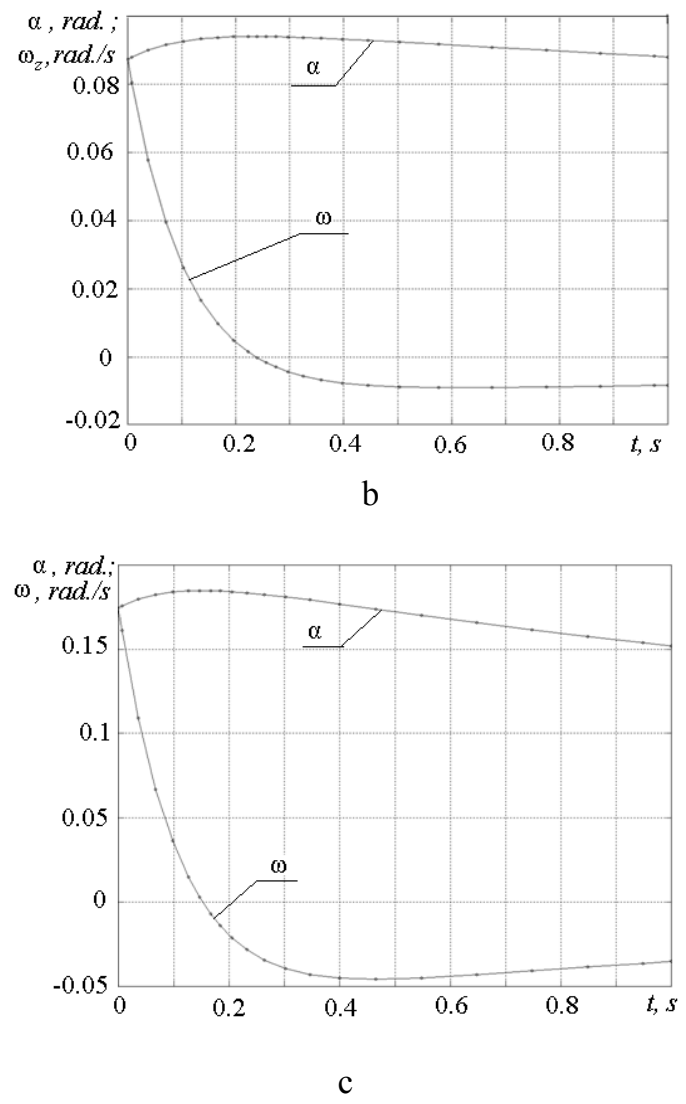

Fig. 6. Dependencies of the angle $\alpha$ and angular velocity $\omega_{z}$ of the AOB from time $t$ at an initial data: (a) $\alpha(0)=0, \omega_{z}(0)=0.0873 \frac{\mathrm{rad}}{\mathrm{s}}\left(5 \frac{\mathrm{deg}}{s}\right) ;(\mathrm{b}) \alpha(0)=$
$=0.0873 \mathrm{rad}(5 \mathrm{deg}), \omega_{z}(0)=0.0873 \frac{\mathrm{rad}}{\mathrm{s}}\left(5 \frac{\mathrm{deg}}{s}\right) ;$ (c) $\alpha(0)=0.1745 \mathrm{rad}(10 \mathrm{deg}), \omega_{z}(0)=0.1745 \frac{\mathrm{rad}}{\mathrm{s}}$ $\left(10 \frac{\mathrm{deg}}{\mathrm{s}}\right)$ 
Coefficients of lift and drag forces approximately equal and change from 0.283 to 0.133 at changing of the AOB attack angle from 0 to $0.14 \mathrm{rad}$. In this range of an angle $\alpha$ the values $X$ and $Y$ greater than weight of the $\mathrm{AOB}$, in particular, at $\alpha=0$ relation $Y / Q=2.2$.

Graphs of the AOB distance covered and its vertical velocity under an action of minimal and maximal lift forces in dependence of time are shown in Fig. 7.

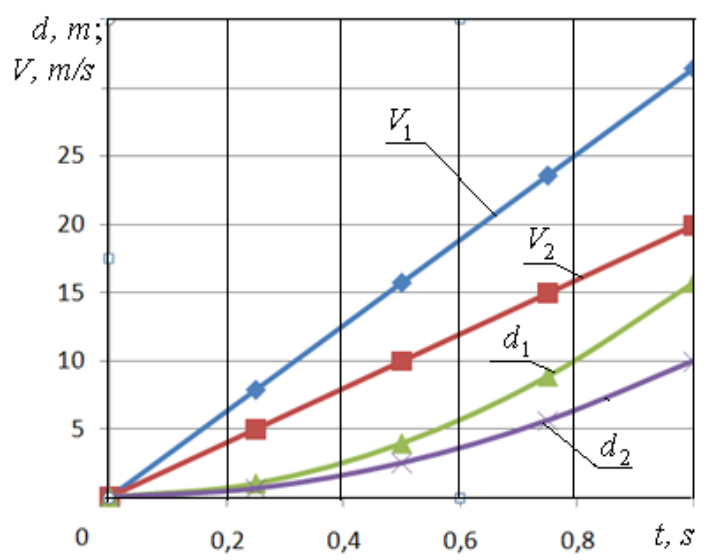

Fig. 7. Dependencies of AOB distance covered and its vertical velocity from time: $d_{1}, V_{1}$ is the AOB distance covered and its vertical velocity at an action of maximal lift force; $d_{2}, V_{2}$ is the AOB distance covered and its vertical velocity at an action of minimal lift force

From an analysis of these calculations follows that the $\mathrm{AOB}$ distance covered is equal-order digits with the size of the AOB.

Therefore the aircraft should not execute maneuvering a preset time after the $\mathrm{AOB}$ dropping.

\section{CONCLUSION}

The research shows the expediency of application method to drop the suspended block with variable geometry Obtained results may be used at calculations of the forced separation of aviation outboard block, and also in the determination of nominal conditions of its applying and during the experiments with it.

\section{REFERENCES}

[1] V. G. Ezhkov, and V. I. Mocryakov, "Suspension device on an aircraft for the cargo, which is thrown in flight," RU Patent 2205133, May, 27, 2003. (in Russian)

[2] Joran Benoit, and Misho Frederic, "System of transportation and discharge of a cargo in flight of the transport aircraft," RU Patent 2513079, Jan. 27, 2014. (in Russian)

[3] N. F. Tupitsin, Kany Zheny, and Zhao Nan, "Method of operative analysis of longitudinal motion cargo, which has thrown from airplane". Electronics and control systems, no. 2(8). Kyiv, NAU, pp. 192-195, 2006. (in Russian)

[4] N. F. Krasnov, Basics of aerodynamic calculation. Aerodynamics bodies of rotation, bearing and control surfaces. Aerodynamics of aircraft, Textbook for students of technical colleges, Moscow, Vyshaya shkola, 496 p., 1981. (in Russian)

[5] A. A. Lebedev, and L. S. Chernobrovkin, The dynamics of the flight of unmanned aerial vehicles,. Textbook for high schools, Moscow, Mashinostroenie, 1973,616 p. (in Russian)

Received February 16, 2016

Tupitsin Nikolay. Candidate of Engineering. Assistant professor.

Aviation Computer-Integrated Complexes Department, National Aviation University, Kyiv, Ukraine.

Education: Moscow Phisics-thechnical Institute, Moscow, Russia (1975).

Research area: dynamic of flight, experimental methods of aerodynamic, aviation simulators.

Publication: 87.

E-mail: nift@mail.ru

Yurchenko Alexander. Candidate of Engineering. Assistant professor.

Aviation Computer-Integrated Complexes Department, National Aviation University, Kyiv, Ukraine.

Education: Moscow Phisics-thechnical Institute, Moscow, Russia (1975).

Research area: operating system, dynamic allocation memory.

Publication: 59.

E-mail: nift@mail.ru

Stepanenko Illia. Master of Engineering.

Education: National Aviation University of Ukraine, Kyiv (2014).

Research area: computer-integrated manufacturing processes.

Publication: 7.

E-mail: STEPANENKO.iLay@gMaiL.com 


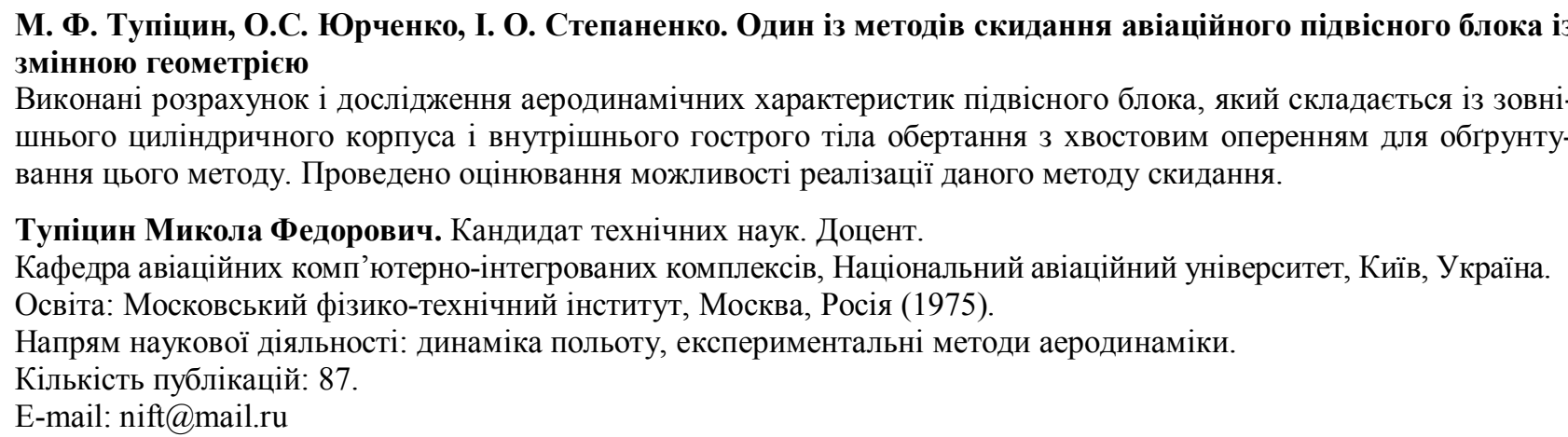

Юрченко Олександр Сергійович. Кандидат технічних наук. Доцент.

Кафедра авіаційних комп'ютерно-інтегрованих комплексів, Національний авіаційний університет, Київ, Україна. Освіта: Московський фізико-технічний інститут, Москва, Росія (1975).

Напрям наукової діяльності: операційні системи, динамічний розподіл пам'яті.

Кількість публікацій: 59.

E-mail: nift@mail.ru

Степаненко Ілля Олександрович. Магістр.

Освіта: Національний авіаційний університет України, м. Київ 2014 рік.

Напрям наукової діяльності: комп'ютерно-інтегровані технологічні процеси.

Кількість публікацій: 7.

E-mail: STEPANENKO.iLay@gMaiL.com

Н. Ф. Тупицин, А. С. Юрченко. И. С. Степаненко. Один из методов сброса авиационного подвесного блока с изменяемой геометрией

Выполнены расчет и исследования аэродинамических характеристик подвесного блока, который состоит из внешнего цилиндрического корпуса и внутреннего острого тела вращения с хвостовым оперением для обоснования этого метода. Проведена оценка возможности реализации данного метода сброса.

Тупицин Николай Федорович. Кандидат технических наук. Доцент.

Кафедра авиационных компьютерно-интегрированных комплексов, Национальный авиационный университет, Киев, Украина.

Образование: Московский физико-технический институт, Москва, Россия (1975).

Направление научной деятельности: динамика полета, экспериментальные методы аэродинамики.

Количество публикаций:87.

Юрченко Александр Сергеевич. Кандидат технических наук. Доцент.

Кафедра авиационных компьютерно-интегрированных комплексов, Национальный авиационный университет, Киев, Украина.

Образование: Московский физико-технический институт, Москва, Россия (1975).

Направление научной деятельности: операционные системы, динамическое распределение памяти.

Количество публикаций:59.

E-mail: nift@mail.ru

Степаненко Илья Александрович. Магистр.

Образование: Национальный авиационный университет Украины, Киев (2014).

Направление научной деятельности: компьютерно-интегрированные технологические процессы.

Количество публикаций: 7.

E-mail: STEPANENKO.iLay@gMaiL.com 